Portland State University

PDXScholar

\title{
Stacking Functions: Identifying Motivational Frames Guiding Urban Agriculture Organizations and Businesses in the United States and Canada
}

\author{
Nathan McClintock \\ Portland State University, n.mcclintock@pdx.edu \\ Michael Simpson \\ University of British Columbia
}

Follow this and additional works at: https://pdxscholar.library.pdx.edu/usp_fac

Part of the Geography Commons, and the Urban Studies and Planning Commons Let us know how access to this document benefits you.

\section{Citation Details}

McClintock, N., \& Simpson, M. (2017). Stacking functions: identifying motivational frames guiding urban agriculture organizations and businesses in the United States and Canada. Agriculture and Human Values, 1-21.

This Post-Print is brought to you for free and open access. It has been accepted for inclusion in Urban Studies and Planning Faculty Publications and Presentations by an authorized administrator of PDXScholar. Please contact us if we can make this document more accessible: pdxscholar@pdx.edu. 


\title{
Stacking functions: Identifying motivational frames guiding urban agriculture organizations and businesses in the United States and Canada
}

\author{
Nathan McClintock ${ }^{1}$ \\ Michael Simpson ${ }^{2}$
}

\begin{abstract}
While a growing body of scholarship identifies urban agriculture's broad suite of benefits and drivers, it remains unclear how motivations to engage in urban agriculture (UA) interrelate or how they differ across cities and types of organizations. In this paper, we draw on survey responses collected from more than 250 UA organizations and businesses from 84 cities across the United States and Canada. Synthesizing the results of our quantitative analysis of responses (including principal components analysis), qualitative analysis of textual data excerpted from open-ended responses, and a review of existing literature, we describe six motivational frames that appear to guide organizations and businesses in their UA practice: Entrepreneurial, Sustainable Development, Educational, Eco-Centric, DIY Secessionist, and Radical. Identifying how practitioners stack functions and frame their work is a first step in helping to differentiate the diverse and often contradictory efforts transforming urban food environments. We demonstrate that a wide range of objectives impact how urban agriculturalists practice UA and that political orientations and discourses differ across geographies, organizational type and size, and funding regime. These six paradigms provide a basic framework for understanding UA that can guide more in-depth studies of the gap between intentions and outcomes, while helping link historically and geographically specific insights to wider social and political economic processes.
\end{abstract}

Keywords: food justice; framing; motivations; non-profit organizations; survey; urban gardens

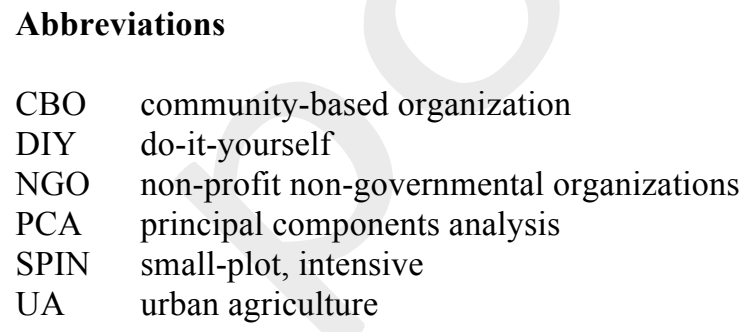

1 Toulan School of Urban Studies \& Planning, Portland State University, P.O. Box 751-USP, Portland, OR 97207, USA

2 Department of Geography, University of British Columbia, 1984 West Mall, Vancouver, BC, V6T 1Z2, Canada 


\section{Introduction}

Countless urban agriculture (UA) initiatives have cropped up across North America with renewed energy and conviction over the past decade. While the enthusiasm driving these various projects may be shared, the underlying motivations are highly divergent and variegated. Consider these four vignettes:

Earth Day 2009 in Portland, Oregon, a self-promoted capital of sustainability. City Council passes a unanimous resolution to build a garden on the grounds of City Hall in order to help "support an economically viable and environmentally and socially sustainable food system" (Portland City Council 2009);

May Day 2013 in Toronto. A loose-knit group of one hundred self-styled revolutionaries, armed with shovels, seeds and compost, converge on the lawns of the Ontario Provincial Legislature to plant a garden as an act of defiance against the "clutches of global capitalism," and in protest of the "state-corporate food system that wreaks environmental devastation and displaces people from their homes through migrant labour" (Bettencourt-McCarthy 2013);

Detroit's Lower Eastside, 2014. About a thousand volunteers assemble to plant 15,000 saplings for the for-profit Hantz Farm, located on 140-acres of residential land (much of it foreclosed) sold by the City of Detroit at fire sale prices (Burns 2016);

San Antonio, Texas, 2015. The Warrior and Family Center Support Center's Healing Garden at Fort Sam Houston wins an award from the American Horticultural Therapy Association in 2015 for its work using gardens to help the healing process of wounded soldiers and their families (KLRU 2015).

These four cases illustrate a diversity of actors, each with different objectives and each practicing forms of UA: a municipal government using UA to promote its city as a model Sustainable City; an informal group using UA to symbolically challenge the capitalist economic order; a for-profit company using UA to invoke the promise of the "new green economy" in a city where many view such initiatives as speculative land grabs; and the US military relying on UA for therapeutic purposes that are explicitly apolitical, but which are inseparable from the politics and human costs of the Global War on Terror.

Debates whether UA radically challenges the prevailing economic and political order, whether it contributes to moderate changes or improvements to people's condition without threatening the structural conditions, or whether it actually serves as a flanking mechanism that shores up processes of neoliberalization have drawn many scholars into the fray (Pudup 2008; Rosol 2012; Weissman 2015). This debate has typically approached UA as though it has a clear and coherent structural role, but as Lovell (2010) has argued, UA is multifunctional. Scholars have demonstrated the range of ecological and social benefits it can provide, from fostering biodiversity (Lin et al. 2015) and reducing greenhouse gas emissions (Kulak et al. 2013) to enhancing food security (Orsini et al. 2014) to building community (Carolan and Hale 2016), as well as the range of motivations driving UA (Draper and Freedman 2010; Kortright and Wakefield 2011; Guitart et al. 2012; Schupp and Sharp 2012; Blecha and Leitner 2013; Drake and Lawson 2014a; Taylor and Lovell 2014; Scheromm 2015; Taylor and Lovell 2015; McClintock et al. 2016; Nordh et al. 2016; Pourias et al. 2016). Moreover, practitioners of UA may simultaneously engage dominant and counter-hegemonic discourses, at once maintaining and challenging different aspects of the status quo, albeit at different scales (McClintock 2014).

What the scholarship on UA reveals - sometimes implicitly, sometimes explicitly-is that the motivation to engage in UA often arises in response to a specific confluence of social 
relations, political economic conditions, and historical-geographic contingencies (Lawson 2005; Moore 2006; McClintock 2010; White 2011; Brinkley and Vitiello 2014). Different types of organizations may therefore function in different ways, with some challenging dominant political economic structures and others supporting neoliberal logics or structures of racial oppression (Reynolds and Cohen 2016; Sbicca 2016).

How these motivations differ between cities, organizational types and size, and funding contexts is nevertheless vague in the literature. How these different motivations work together is also unclear. Are practitioners motivated by UA's ecological benefits also interested in food sovereignty? To what extent do concerns with social justice go hand in hand with entrepreneurial motivations? Moreover, how might we conceive of common groupings of motivations as frames that differentially guide UA practice, and how might we position these frames within larger social, political economic, and historical-geographical contexts? The research we present here begins to address these lacunae.

Drawing on the results of an online survey of 251 UA organizations and businesses in 84 US and Canadian cities, we employ a mixed-methods approach to identify not only which motivations are most common among practitioners, but also how they differ across geographies, organizational types, and funding regimes. Further, we focus on which motivations most commonly co-occur, i.e., which are most often "stacked" or "bundled". Identifying these bundles in turn allows us to home in on a set of motivational frames that typically guide UA practice. We consider these frames not only as "schemata of interpretation" that work "to locate, perceive, identify, and label" (Goffman 1974, 21), but also for their ability to motivate and shape practice and collective action "in ways intended to activate adherents, transform bystanders into supporters, exact concessions from targets, and demobilize antagonists" (Snow 2008, 385).

We also recognize the spatio-temporal aspects of such collective action frames, where "place frames" (Martin 2003) work discursively to mobilize actors around localities, and "scale frames" (Kurtz 2003) work to contextualize local struggles at such sites within larger-scale movements. Such frames work discursively, and it is precisely the gap between discursive frames and material outcomes that many critical UA scholars have focused on (Lyson 2014; McClintock 2014). While the disjuncture between discourse and action lies outside the scope of our paper, we nevertheless maintain that attention to the frames employed by UA practitioners can shed new light on UA practice, and the ways in which geography, funding, and organizational size mediate it. Given our assertion that the motivations underlying UA are relational, attention to different motivational frames can therefore help us to better situate UA within specific political economic and geographic contexts.

We proceed by describing our methodology before presenting an overview of results of our survey. We then describe, in turn, each of the six frames we have identified, paying particular attention to ways that certain motivations overlap across frames, and the emphasis of each on economic, environmental, and social concerns.

\section{Methodology}

We conducted an online survey over six weeks between February and April 2013. We sent the survey link directly to 548 businesses and organizations from 50 cities in Canada and the United States, including most major Canadian metropolitan areas and a geographically representative sample of cities from the US. Recipients were identified both from professional networks and via internet searches for businesses, non-profits, and community groups involved 
in "urban agriculture", "urban gardening", and "urban farming". Survey respondents identified in snowball fashion an additional 71 respondents from 25 cities, who then received the survey directly. We also disseminated the survey via several national list-serves in both Canada and the US, and to over 100 additional contacts involved in UA unaffiliated with an organization or business who we asked to forward the survey to their own contacts involved with UA organizations or businesses. ${ }^{1}$ Survey participants could choose to take the survey in English or French, or request a copy of the survey in Spanish.

For the purposes of this article, we used a mixed-methods approach to analyze responses to two of the survey questions, the first of which was an open-ended question asking respondents to "describe what motivates your organization to be involved in urban agriculture." This question was followed by a multiple-choice question: "Which of the following categories best describe the primary motivations of your organization's urban agriculture projects?" For this question, respondents were instructed to select all applicable choices from a list of twenty motivations which we developed based on a review of the literature and our own experiences working with a variety of UA organizations in the US and Canada. The open-ended question appeared separately before the multiple-choice question so as not to bias responses with pre-conceived choices or terminology. ${ }^{2}$

Using JMP 11 software (SAS Institute, Cary, NC), we first calculated descriptive statistics (means, frequency distributions, etc.) and then conducted a Kruskal-Wallis rank-sum test to determine significant differences between what types of organization or business indicated a particular motivation. ${ }^{3}$ In addition to analyzing by organizational type - business, non-profit non-governmental organization (NGO), community-based organization (CBO), school, or governmental organization - we also tested whether the size of organization (as measured by the number of paid staff dedicated to UA program and the size of the annual budget dedicated to UA programs) has a significant effect on motivation. Similarly, we tested whether the amount and origin of organizational funding had a significant relationship to motivation. To determine if there were significant geographic differences in what motivates organizations and businesses to engage in UA, we also grouped responses by state/province into larger regional groups to allow for statistical comparison (see Table 1). Additionally, we compared responses from the three metropolitan areas with the highest number of responses (Portland, the San Francisco Bay Area, and Montreal) to the rest of Canada and the rest of US responses.

Next, we conducted principal components analysis (PCA) to explore how these motivations covary. Widely used in behavioral research, PCA is a way to reduce a large number of observed variables into a smaller subset of latent variables. ${ }^{4}$ A Barlett test helped us to

\footnotetext{
${ }^{1}$ National list serves included COMFOOD, Food Planning, CFSC Urban Agriculture, as well as those belonging to the AAG Geographies of Food and Agriculture Specialty Group, the Canadian Association of Geographers, and Le collectif de recherche en l'aménagement paysager et en agriculture urbaine durable (CRAPAUD).

${ }^{2}$ For data related to the survey's other questions, see McClintock and Simpson 2014.

${ }^{3}$ A rank-sum test used for non-parametric, categorical data, the Kruskal-Wallis test determines if the mean ranks are the same in all analytical groups. The result is a chi-square approximation that can be used as a measure of probability of difference between analytical groups.

4 The procedure transforms the variation in the original variables into a smaller set of uncorrelated linear combinations of these variables, or principal components, which are eigenvectors of the covariance matrix of the variables. The first principal component accounts for as much of the variance in the data as possible, with each subsequent component accounting for as much of the remaining variance as possible (Kroonenberg 2004). Subsequent factor analysis then reduces these principal components into a smaller subset of factors. Rotating these factors in turn makes it easier to interpret how each observed variable correlates with each of the factors; for our analysis we used the default varimax rotation on the six factors extracted from the PCA.
} 
determine that our dataset could be reduced into six significant principal components. We then ran a factor analysis on these six principal components to allow for interpretation of "factor loading", that is, how each observed variable - in our case, each motivation - correlated with each of the six latent variables.

Table 1 Geographic groupings for analysis

\begin{tabular}{lll}
\hline Geographic grouping & N & States/provinces included in group (N) \\
\hline Northeast / Mid-Atlantic & 24 & CT (1); DC (1); MA (2); MD (5); NY (11); RI (4) \\
Upper Midwest & 27 & IL (10); MI (5); MN (8); WI (3) \\
California & 33 & CA (33) \\
Oregon / Washington & 56 & OR (43); WA (13) \\
Other US & 42 & AR (2); AZ (2): CO (4); FL (3); GA (6); KS (1); KY (1); LA (1); MO (1); MT \\
& & (1); NC (4); NE (3); NM (3); NV (2); OH (4); TN (3); UT (2) \\
Quebec & 29 & QC (29) \\
Other Canada & 40 & AB (2); BC (20); NS (1); NT (1); ON (15); SK (1) \\
\hline
\end{tabular}

We next analyzed the open-ended responses, using Dedoose qualitative data analysis software to help us organize, code, and excerpt text based on the twenty pre-determined motivational categories and other emergent themes. Triangulating the six factors derived from PCA with both the coded, open-ended responses, we identified six motivational frames comprised of bundles of motivations that interrelate and commonly appear together when practitioners describe what guides their engagement with UA. We drew on existing literature to help define the contours of the six frames, as well as to place the frames within particular historical and geographic contexts.

The frames we have identified therefore emerged both from the PCA/factor analysis and qualitiative assessment of open-ended responses and extant studies of UA. We want to emphasize, however, that we do not privilege these frames as objective "truth" simply because they emerged in part from statistical calculations. We consider PCA first and foremost an exploratory data reduction tool that can help bring these frames into focus while guiding our qualitative analysis of open-ended responses. Typologies such as our frames by design reduce complex relations into simpler ones; following Sayer (1989), we recognize that the abstraction of observations into analytical categories inherently does "violence" to the world they intend to represent. Moreover, we hold that all knowledge production is shaped by the observer and is therefore always subjective to a certain extent, even when statistical analyses suggest otherwise. For this reason, these six frames reflect not only how respondents "stack" their perceptions of UA's functions, but also how we as researchers, in turn, have stacked their responses into a typology. Although such categories are inherently reductionist, we believe they are, nevertheless, a useful heuristic that offers useful insights into the practice of UA while providing a framework to guide more intensive qualitative or mixed-methods research on the motivations of particular groups of UA practitioners.

\section{Stacked Functions and Motivational Frames}

Overall, we received 275 complete responses from 108 different municipalities in the two countries (see Fig. 1). Of the total number of UA groups that we contacted directly, 125 
responded from 46 different cities, a response rate of 20\%. We ultimately omitted 34 responses from the final dataset for a variety reasons: seven were from outside the US or Canada; three were from respondents producing solely in rural areas; eight were not engaged in any sort of agricultural production; and seven from groups that submitted multiple responses. ${ }^{5}$ Ultimately, we retained a total of 251 responses (229 in English and twenty-two in French), 120 of which we had contacted directly, and 131 contacted via snowball dissemination via forwarding, list-serves, etc.

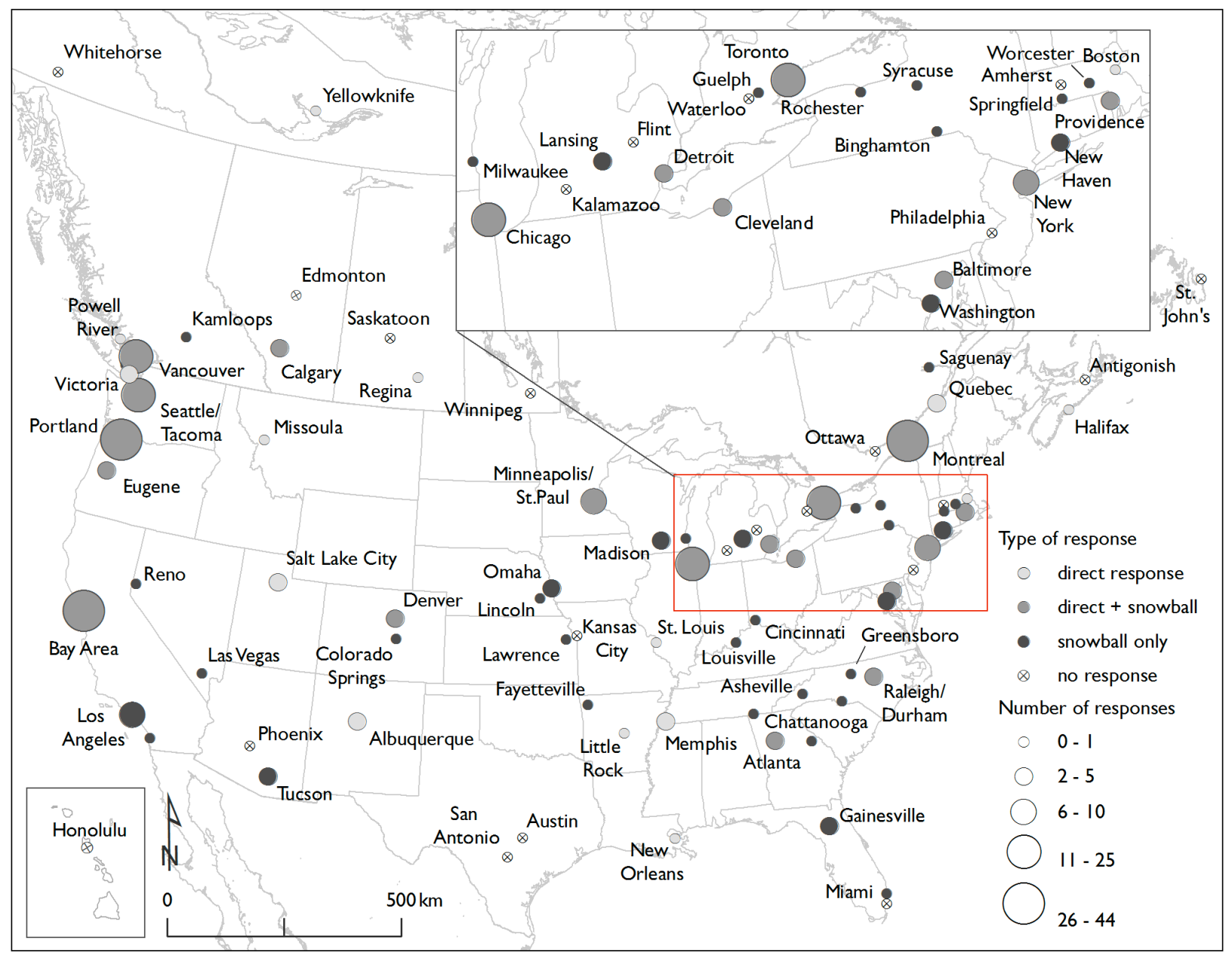

Fig 1 Geographic distribution of surveyed urban agriculture organizations and businesses. Our final dataset consisted of survey responses from 251 businesses and organizations across 84 cities in the United States and Canada. Six hundred and eighteen businesses and organizations were contacted directly, of which 125 responded -a $20 \%$ response rate. Other businesses and organizations that responded were contacted via "snowball" dissemination. Not pictured: Inuvik, NT (no response). Note that some suburbs/conurbations have been aggregated (e.g., Bay Area includes San Francisco, Oakland, Berkeley; Montreal includes Longueuil and Laval; Vancouver includes Burnaby and Richmond)

\footnotetext{
${ }^{5}$ In cases where members of a single organization submitted more than one response, we compared the duplicate responses to confirm that that they were not substantively different, then retained the response that was filled out more completely and/or filled out by someone with more management responsibility in the organization.
} 
Responses came from 84 cities, but more responses came from Portland than from other cities, likely due to the origin of the study. The San Francisco Bay Area (e.g., San Francisco, Oakland, Berkeley, Alameda) and Montreal were also heavily represented, as were Vancouver, Toronto, Seattle, Chicago, and New York (see Fig. 1). Sixty-two of the responses from the final dataset were completed by businesses and 189 from other types of organizations, including non-profits and charities, school groups, informal community-based groups, and governmental departments or agencies (Table 2). Henceforth, when we refer to "organizations" in this paper, we are referring to all of these groups as opposed to for-profit businesses. Table 3 displays the distribution of budget and staff size by organization type.

Table 3 Characteristics of surveyed businesses and organizations by type

\begin{tabular}{|c|c|c|c|c|c|c|c|}
\hline \multicolumn{8}{|c|}{ Organization type } \\
\hline Business & & GO & Comn & $y$ org & & & Governmental \\
\hline$\%$ & $\mathrm{~N}$ & $\%$ & $\mathrm{~N}$ & $\%$ & $\mathrm{~N}$ & $\%$ & $\mathrm{~N}$ \\
\hline
\end{tabular}

Annual budget dedicated to UA programs

$<\$ 1 \mathrm{~K}$

$\$ 1 \mathrm{k}$ to $5 \mathrm{k}$

$\$ 5 \mathrm{k}$ to $10 \mathrm{~K}$

$\$ 10 \mathrm{k}$ to $50 \mathrm{~K}$

$\$ 50 \mathrm{~K}$ to $100 \mathrm{~K}$

$>\$ 100 \mathrm{~K}$

$\begin{array}{rr}10 & 22 \% \\ 8 & 17 \% \\ 11 & 24 \% \\ 6 & 13 \% \\ 2 & 4 \% \\ 9 & 20 \%\end{array}$

$\begin{array}{ll}15 & 18 \% \\ 14 & 16 \% \\ 20 & 24 \% \\ 10 & 12 \% \\ 15 & 18 \% \\ 11 & 13 \%\end{array}$

$\begin{array}{rr}14 & 47 \% \\ 12 & 40 \% \\ 0 & 0 \% \\ 1 & 3 \% \\ 0 & 0 \% \\ 3 & 10 \%\end{array}$

\begin{tabular}{l}
\hline Organization type \\
\hline Private for-profit business \\
Non-profit / non-governmental organization (NGO) \\
Community-based organization (CBO) \\
School or university \\
Government organization or agency \\
\hline
\end{tabular}

Number of paid staff dedicated to UA programs

\begin{tabular}{|c|c|c|c|c|c|c|c|c|c|c|}
\hline None & 15 & $29 \%$ & 26 & $28 \%$ & 26 & $84 \%$ & 4 & $17 \%$ & 0 & $0 \%$ \\
\hline 1 & 11 & $21 \%$ & 8 & $9 \%$ & 2 & $6 \%$ & 2 & $9 \%$ & 4 & $29 \%$ \\
\hline 2 & 6 & $12 \%$ & 22 & $24 \%$ & 1 & $3 \%$ & 7 & $30 \%$ & 2 & $14 \%$ \\
\hline 3 to 4 & 11 & $21 \%$ & 17 & $18 \%$ & 0 & $0 \%$ & 3 & $13 \%$ & 3 & $21 \%$ \\
\hline 5 to 9 & 5 & $10 \%$ & 13 & $14 \%$ & 1 & $3 \%$ & 6 & $26 \%$ & 3 & $21 \%$ \\
\hline $10+$ & 4 & $8 \%$ & 7 & $8 \%$ & 1 & $3 \%$ & 1 & $4 \%$ & 2 & $14 \%$ \\
\hline
\end{tabular}

Respondents indicated a wide diversity of motivations for engaging in UA work (see Fig. 2), ranging from community building ( $80 \%$ of all groups) to spirituality ( $4 \%$ of all groups). Responses underscore that multiple motivations drive organizations and businesses to engage in UA in North America. On average, organizations categorized their efforts using $8.9( \pm 0.2)$ different motivations, with no significant difference in the number of motivations by geography or organization type. Organizations with UA budgets of less than $\$ 1,000$ indicated fewer motivations ( $7.2 \pm 0.5$ motivations) than those with higher budgets. 


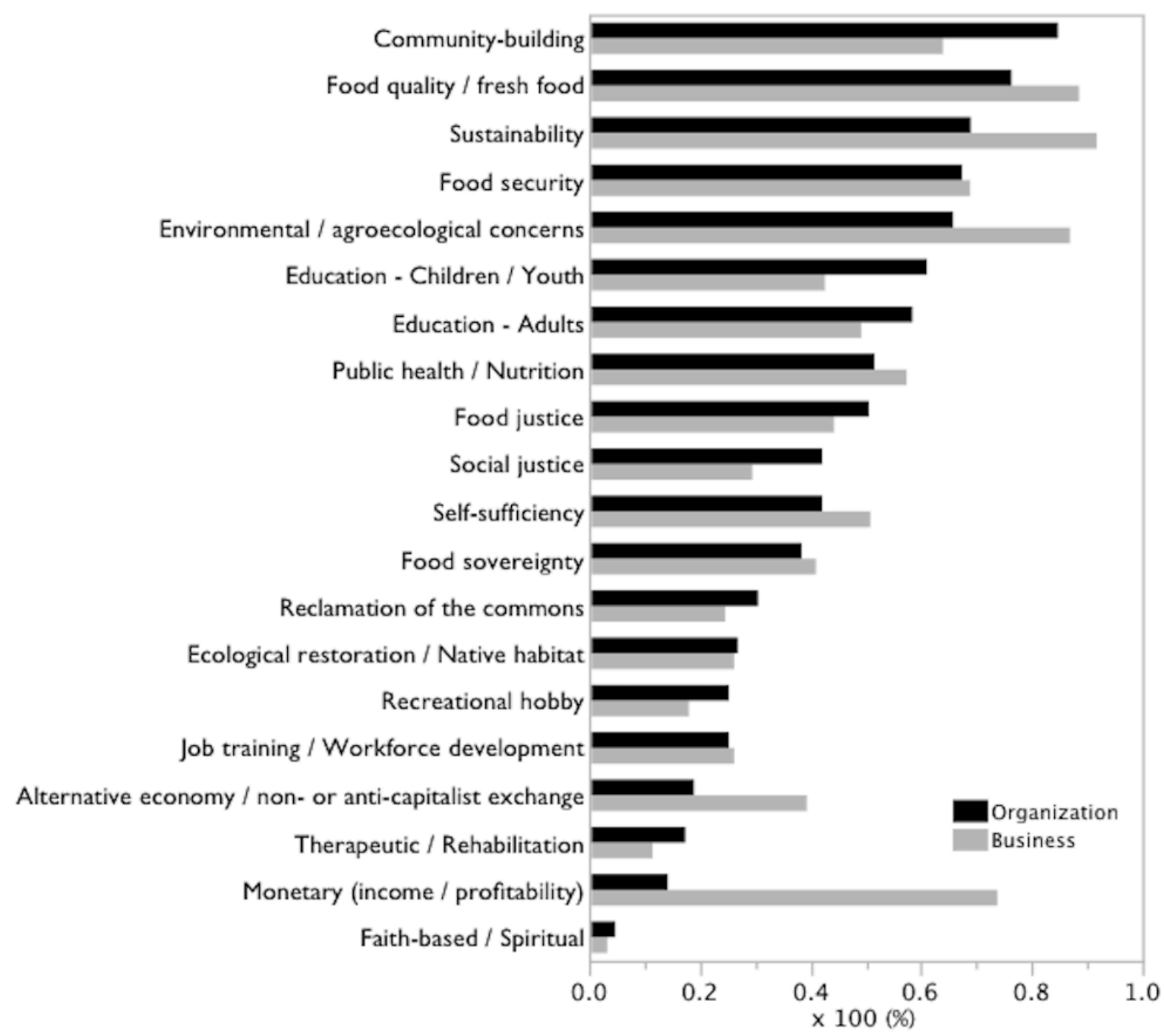

Fig 2 Primary motivations of North American organizations $(n=189)$ and businesses $(n=62)$ engaged in urban agriculture

As we address in detail in the sections that follow, there were some significant differences in motivations between organizational types, size, and origin of funding, as well as geographic differences that, as we discuss below, may shape the predominance of a particular frame among UA practitioners. Table 4, for example, reports significant relationships between several motivations and both the size of an organization's budget allocated to UA programs and the number of employees working on UA. Results further demonstrate that UA organizations and businesses clearly recognize and embrace the multifunctionality of their work; many respondents invoked "stacked functions"-an ecological term frequently invoked in permaculture-to emphasize the multiple and overlapping focal areas of their project and to describe how "urban food production provides a multitude of public benefits, ranging from education/awareness to urban reclamation to stormwater diversion" (\#239, business, Minneapolis). For example, a nonprofit in Memphis is "working at the convergence of issues related to blighted property, food insecurity, and community development. We believe that our gardening program and policy 
advocacy can tackle all of these issues at once" (\#254). Others describe their recognition of UA's multiple functions over time. The leader of one informal group in Los Angeles explains how the motivations were primarily ecological at the beginning, but have expanded with time: "Initially, I wanted to provide a space where people, especially children, could connect with the earth and their food in a way that seems less available now. But I also now see it as a way to improve access to healthy food and to build community relationships" (\#163).

Principal components analysis revealed six different factors explaining covariance between responses (see Table 5; the factor loading for each variable listed is the correlation between the variable and each of the factors). While these six factors cumulatively account for only $54 \%$ of variance overall, they nevertheless reveal how certain values and motivations driving UA practice tend to occur in particular combinations, and serve as the starting point for our identification of six motivational frames, the qualitative characteristics of which emerged from our coding of open-ended responses and review of the literature. The six frames are displayed in Table 6: the Sustainable Development frame, the Educational frame, the Entrepreneurial frame, the Do-It-Yourself (DIY) Secessionist frame, the Eco-Centric frame, and the Radical frame. Based on the factor loading, we have placed the six frames relationally by identifying both overlaps between particular motivations (see Fig. 3), and by situating each frame along three axes of concernenvironmental, social, and economic - based on the size of the factor loading of the various variables (see Fig. 4). Indeed, these frames are by no means mutually exclusive; many respondents clearly operate within multiple motivational frames. However, as Campbell (1996) argues, increased attention on set of concerns (e.g., environmental) inevitably results in neglect of another set (e.g., profitability). Visualizing these different frames relationally along the three axes helps to clarify the weight of such concerns in each frame.

Table 4 Significant positive $(+)$ and negative $(-)$ relationships between motivations and size of UA budget and number of paid staff

\begin{tabular}{|c|c|c|c|}
\hline Motivation & & $\begin{array}{l}\text { Budget } \\
\text { for UA }\end{array}$ & $\begin{array}{l}\text { Number } \\
\text { of } \\
\text { paid UA } \\
\text { staff }\end{array}$ \\
\hline $\begin{array}{l}\text { Monetary } \\
\text { (income / profitability) } \\
\text { Job training / Workforce } \\
\text { development }\end{array}$ & & $+* * *$ & $+* *$ \\
\hline Recreational hobby & & $-* *$ & $-* *$ \\
\hline $\begin{array}{l}\text { Therapeutic / } \\
\text { Rehabilitation } \\
\text { Education - Children / } \\
\text { Youth }\end{array}$ & & $\begin{array}{l}-* \\
+* * *\end{array}$ & \\
\hline Sustainability & & $+\dagger$ & \\
\hline Food security & & $+*$ & $+*$ \\
\hline Food justice & & & $-*$ \\
\hline Food sovereignty & & & $-\dagger$ \\
\hline Social justice & & & $-* *$ \\
\hline \multirow[t]{3}{*}{$\begin{array}{l}\text { Alternative economy / } \\
\text { non- or anti-capitalist } \\
\text { exchange }\end{array}$} & & & $-* *$ \\
\hline & $\mathrm{N}$ & 190 & 251 \\
\hline & df & 6 & 5 \\
\hline
\end{tabular}


Table 5 Rotated factor loading of principal components analysis of survey respondents' motivations to engage in urban agriculture. Bolded factor loadings indi

\begin{tabular}{|c|c|c|c|c|c|c|}
\hline \multirow[b]{2}{*}{ Motivation } & \multirow[b]{2}{*}{1} & \multirow[b]{2}{*}{2} & \multicolumn{2}{|c|}{ Factor } & \multirow[b]{2}{*}{5} & \multirow[b]{2}{*}{6} \\
\hline & & & 3 & 4 & & \\
\hline Food quality / fresh food & 0.6924 & 0.0491 & 0.0397 & 0.0007 & -0.0007 & 0.2424 \\
\hline Public health / Nutrition & 0.6376 & 0.2423 & 0.0545 & 0.1266 & -0.2031 & 0.0130 \\
\hline Self-sufficiency & 0.5933 & 0.1131 & 0.1960 & 0.0039 & 0.1684 & -0.0779 \\
\hline Food security & $\mathbf{0 . 5 5 3 6}$ & 0.2445 & -0.2057 & 0.2471 & 0.0362 & -0.1037 \\
\hline Sustainability & 0.5212 & 0.0461 & 0.0933 & 0.1973 & 0.3841 & 0.2083 \\
\hline Community-building & 0.3438 & 0.2006 & 0.2151 & 0.1693 & -0.0552 & -0.4041 \\
\hline Social justice & 0.0271 & 0.7975 & 0.0220 & 0.2119 & 0.0049 & 0.0839 \\
\hline Food justice & 0.2491 & 0.7859 & 0.0312 & 0.0505 & 0.0403 & 0.0286 \\
\hline Food sovereignty & 0.4226 & 0.6121 & -0.0353 & -0.0672 & -0.1106 & 0.0149 \\
\hline Therapeutic / Rehabilitation & 0.2066 & -0.0366 & 0.6382 & 0.1071 & -0.2692 & -0.0046 \\
\hline Recreational hobby & 0.0812 & -0.1112 & 0.6115 & 0.0274 & -0.0067 & -0.1771 \\
\hline Reclamation of the commons & 0.0082 & 0.3259 & 0.5940 & -0.1287 & 0.1978 & -0.0802 \\
\hline Ecological restoration / Native habitat & -0.0733 & 0.0283 & 0.5339 & 0.1311 & 0.1001 & 0.1487 \\
\hline Faith-based / Spiritual & 0.1324 & 0.1338 & 0.1345 & -0.0748 & -0.6513 & 0.0433 \\
\hline Education - Children / Youth & 0.0906 & 0.1151 & 0.1461 & 0.7851 & -0.0692 & -0.0060 \\
\hline Education - Adults & 0.2177 & 0.0516 & 0.0241 & 0.6834 & 0.2147 & -0.0641 \\
\hline Environmental / agroecological concerns & 0.2619 & 0.0319 & 0.2606 & 0.1682 & 0.5453 & 0.3485 \\
\hline $\begin{array}{l}\text { Alternative economy / non- or anti- } \\
\text { capitalist exchange }\end{array}$ & 0.2568 & 0.3545 & 0.1908 & -0.2456 & 0.5345 & -0.1753 \\
\hline Job training / Workforce development & 0.0701 & 0.3628 & -0.0015 & 0.2419 & -0.1626 & 0.6418 \\
\hline Monetary (income / profitability) & 0.2324 & -0.0351 & -0.0455 & -0.3809 & 0.1259 & 0.6397 \\
\hline Variance explained by factor & 2.4970 & 2.2184 & 1.7085 & 1.6238 & 1.4575 & 0.7446 \\
\hline$\%$ & 12.5 & 11.1 & 8.5 & 8.1 & 7.3 & 6.6 \\
\hline Cumulative \% & 12.5 & 23.6 & 32.1 & 40.2 & 47.5 & 54.2 \\
\hline
\end{tabular}


Table 6 Six motivational frames as informed by factors identified by principal components analysis and qualitative content analysis

\begin{tabular}{|c|c|c|}
\hline Factor & Motivational frame & Dominant motivations \\
\hline \multirow[t]{7}{*}{1} & "Sustainable & Food quality/fresh food \\
\hline & Development", & Public health/nutrition \\
\hline & & Food security \\
\hline & & Sustainability \\
\hline & & Self-sufficiency \\
\hline & & Food sovereignty \\
\hline & & Community-building \\
\hline \multirow[t]{5}{*}{2} & "Radical" & Social justice \\
\hline & & Food justice \\
\hline & & Food sovereignty \\
\hline & & Reclamation of the commons \\
\hline & & $\begin{array}{l}\text { Alternative economy/ } \\
\text { anti-capitalist exchange* }\end{array}$ \\
\hline \multirow[t]{6}{*}{3} & “DIY Secessionist” & Reclamation of the commons \\
\hline & & Recreational hobby \\
\hline & & Therapeutic/rehabilitation \\
\hline & & $\begin{array}{l}\text { Alternative economy/ } \\
\text { anti-capitalist exchange }\end{array}$ \\
\hline & & Community-building* \\
\hline & & Self-sufficiency* \\
\hline \multirow[t]{2}{*}{4} & "Educational" & Education (youth) \\
\hline & & Education (adults) \\
\hline 5 & "Eco-centric" & Environmental/agroecological \\
\hline \multirow{4}{*}{6} & & $\begin{array}{l}\text { Sustainability } \\
\text { Monetary (income/ }\end{array}$ \\
\hline & "Entrepreneurial" & $\begin{array}{l}\text { Monetary (1ncome/ } \\
\text { profitability) }\end{array}$ \\
\hline & & Job training/ \\
\hline & & workforce development \\
\hline
\end{tabular}






Fig 3 The overlapping of motivations across multiple frames

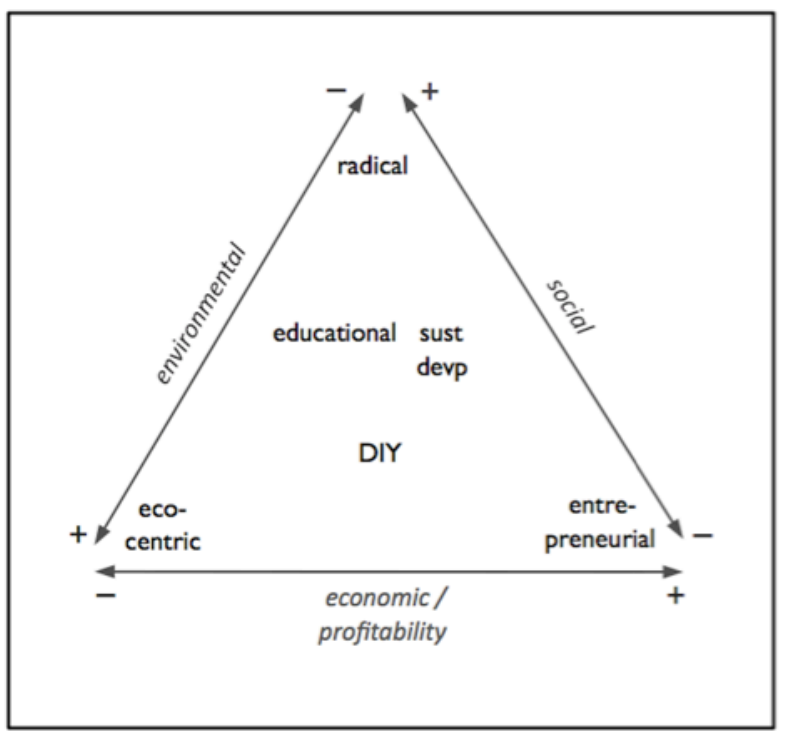

Fig 4 Six motivational frames situated relationally along three axes of concern: environmental, social, and economic (profitability) 
The Entrepreneurial frame

The Entrepreneurial frame consists of a cluster of motivations among UA practitioners that value capitalist economic development and environmental concerns, but which also downplay social concerns. Unsurprisingly, the majority of the UA businesses surveyed (76\%) were motivated by monetary objectives, and businesses cited income/profitability significantly more than other types of organizations $(p<0.001)$. But, the UA practitioners who subscribe to what we are calling the Entrepreneurial frame are not defined by their interest in profit alone. This frame is characterized by an aspiration to see UA serve as a tool of community economic development that offers opportunities for right livelihood that reinvigorate local economies.

While entrepreneurial approaches to UA production have a notable history that arguably include the Vacant Lot Cultivation Associations of the 1890s (Drake and Lawson 2014b), Kaufman and Bailkey (2000) note that efforts to make urban farming in US and Canadian cities "profitable" date back to the 1980s, but received a real boost with the implementation of the USDA's Community Food Project competitive grant program in 1996. Since then, enthusiasm for commercial urban agriculture has soared, particularly with the advent of "SPIN" ("small-plot, intensive") farming and roof-top gardens such as the Brooklyn Grange and Gotham Greens that produce high-value crops for farm-to-table restaurants (Christensen 2007; Buehler and Junge 2016). This Entrepreneurial frame situates UA as one part of a revitalized and environmentally sound food system that directly links local producers with distributors and consumers, providing jobs and providing economic value at each step (Norberg-Hodge et al. 2002; Heying 2010). This food economy is said to create a multiplier effect by keeping dollars circulating within the local economy, thereby providing jobs as well as niche markets for local foods. As we allude to in the introduction with the case of Hantz Farms in Detroit, however, such entrepreneurial approaches are sometimes fraught with contention over who reaps the benefits.

For many organizations and businesses alike, UA has a key role to play in "support[ing] a vibrant local community and economy" (\#22, business, Portland, OR). In the words of one nonprofit in Chattanooga, "We work to connect our population to our local foodshed. We believe that a strong local agricultural economy is the backbone for our local economy" (\#84). Other efforts are even more transformative in scale and scope. As expressed by one Detroit business owner, "We see urban agriculture as an opportunity for our city (and others) to rebuild our economy, restore our health and environment, provide good work and education, and solve many other problems that currently plague us" (\#170). A Portland business owner echoes this sentiment, motivated to provide "fresh organic local vegetables for neighbors to support a vibrant local community and economy, provide healthy food, and reduce the distance that food travels from field to plate" (\#22). Moreover, some emphasize that entrepreneurial UA should be supported, not hindered, by government policy. As one Bay Area NGO expressed, "It's everyone's right to grow and sell food produced in their community" (\#53, Oakland).

Responses further demonstrate that UA businesses are not only motivated by income/profitability, but also by broader environmental concerns and commitment to sustainable development. Curiously, businesses more commonly identified both environmental concerns as a primary motivation than did other types of organizations $(88 \%$ of businesses versus $66 \%$ of organizations). The same was true for sustainability ( $91 \%$ of businesses versus $69 \%$ of organizations), with some businesses explicit in linking UA with sustainability, or more specifically "sustainable cities, land use issues, sustainable business models, and food access" 
(\#62, business, Lansing, MI). Overall, businesses and NGOs were more likely $(\mathrm{p}<0.05)$ to cite sustainability as a motivation than schools, government, or CBOs. Other businesses draw linkages between the work they do and its benefits to the environment without specifically mentioning sustainability. The mission of one urban farm in Albuquerque is to provide "employment that is beneficial to the community and local and global ecology" (\#113). Other businesses describe their motivations in more general terms, for example, "socially-responsible entrepreneurialism and food security issues" (\#146, Toronto) or "creating a better world while trying to make a modest living at the same time" (\#210, Toronto).

As we discuss in more detail in the next section, this tendency of businesses and organizations to link UA with environmental concerns and with the larger food system is consistent with sustainability discourse employed by local food systems advocates and policymakers over the past decade which contends that UA can play a central role in a city's green economic development. One Bay Area business reports, "We hope to identify the benefits in order to promote and showcase them. We also hope to identify the obstacles in order to work towards breaking them down" (\#204, San Francisco). To this end, several businesses also discuss the importance of proving that urban farming is economically viable. In addition to concern over "food access issues as well as an interest in reducing the carbon impact of food systems," a New Orleans business is "also interested in testing (and hopefully proving!) that a small-scale urban and organic farm can be financially viable and provide a decent wage to our farmer" (\#193). A Minneapolis business responded,

We are striving to establish a financially viable urban farm model for the Twin Cities area, while being good ecological stewards and building social capital. We believe in urban farms as a key piece of a sustainable and just local foods movement, and see their role as key towards building food security and community resiliency. (\#165)

The motivations of "job training and workforce development" were a significant factor associated with the Entrepreneurial frame, and were identified as motivations by a quarter of organizations and a third of businesses. Indeed, it was significantly more important for larger organizations, i.e., those with five or more paid staff, suggesting that, like food security and sustainability, job training is an area that funders are willing to support.

Paradoxically, although some groups aspire to demonstrate the financial viability of UA, many practitioners share the belief that UA is not a huge moneymaker. Echoing recent literature underscoring UA's limited potential to contribute to economic development (Vitiello and WolfPowers 2014), one UA business owner in Portland warns, "There is no money in urban agriculture. Forget health insurance or any savings" (\#13).

The Sustainable Development frame

The most all-encompassing statistical cluster of motivations includes food security, food quality, public health/nutrition, sustainability, self-sufficiency, and community-building. At first blush, such an all-encompassing grouping may seem to hold little analytical purchase. But given the frame's encompassing of a broad suite of concerns commonly addressed under the mainstream umbrella of sustainability, we refer to this wide-ranging cluster of motivations as the Sustainable Development frame. 
Following in the tradition of the 1987 Brundtland Commission Report on sustainable development, this cluster of motivations cuts across diverse environmental, social, and economic goals. As the member of one Portland collective explains, UA "hits all three parts of the triple bottom line for sustainability: ecological sustainability of urban environments, social and food justice issues, and economic security" (\#4). Consequently, in Fig. 4 we place this motivational frame roughly in the middle of social, environmental, and economic axes, but leaning somewhat towards greater concern for profitability.

Sustainability, itself, was the single most common motivation cited by all the businesses we surveyed, and it was also the third most common motivation among all organizations. However, qualitative responses indicate that UA groups understand the meaning of "sustainability" differently. While some appear to use the word sustainability to describe their specific practices such as delivering produce by bicycle (\#162, business, Detroit) others use the moniker in a more holistic way to describe a "sustainable lifestyle" (\#7, business, Portland). Respondents also associate sustainability with different scales of impact. For example, a CBO in Chicago suggested that its practice contributes to a "sustainable neighborhood" (\#264), whereas an Atlanta NGO emphasized sustainability at a metropolitan regional scale (\#252).

The Sustainable Development frame also incorporates respondents who expressed that they are motivated to improve access to fresh and healthy food and food security, which were often interwoven within a broader sustainability discourse. In the words of a Seattle NGO, "We believe in the power of edible neighborhoods to end hunger and increase health in our communities (\#115). Another school group explains, "We share a dedication to alleviating hunger and creating community food security by cultivating a local sustainable food network" (\#75, Fayetteville, AR). Often respondents were explicit that their efforts to increase food security and access to fresh produce are directed toward low-income communities of color. For instance, one business owner in Los Angeles emphasizes UA's potential role in "increasing quality food access to communities of color that lack basic resources such as full-service grocery stores and non-fast food restaurants" (\#167).

These motivations at the heart of the Sustainable Development frame differ significantly by organizational type and size. Sustainability was most commonly cited by organizations with annual UA budgets of $\$ 10 \mathrm{~K}$ to $\$ 50 \mathrm{~K}$; organizations receiving between a third and two-thirds of their funding from foundations also invoked sustainability more often (see Table 7). Similarly, food security was more frequently cited by organizations with larger budgets (see Fig. 5) and by organizations with two or more paid staff, especially NGOs. Organizations that relied on government funding for the majority of their operating costs also invoked food security more often.

The relationship of food security and sustainability to organization type and size suggests the extent to which the concepts have entered into mainstream discourse surrounding UA, and also that practitioners-particularly businesses and large organizations receiving government funding - have embraced and even shaped this discursive frame in the post-Brundtland era. The motivations invoked by those respondents embracing the Sustainable Development frame mirror claims made in the academic literature and popular discourse which link UA to improved food security enhanced nutrition, physical activity, and public health and sustainability, more broadly (Smit et al. 1996; Mougeot 2005; Viljoen 2005; van Veenhuizen 2006). 
Table 7 Significant positive $(+)$ and negative $(-)$ relationships between proportion of funding source and motivations $(\mathrm{N}=212)$

\begin{tabular}{|c|c|c|c|c|c|}
\hline \multirow[b]{2}{*}{ Motivation } & \multicolumn{5}{|c|}{ Funding source } \\
\hline & Governmental & Foundation & $\begin{array}{l}\text { Corporate } \\
\text { donations }\end{array}$ & $\begin{array}{c}\text { Individual } \\
\text { donations }\end{array}$ & Sales \\
\hline Monetary & $-* * *$ & & & $-* * *$ & $+* * *$ \\
\hline $\begin{array}{l}\text { Job training / Workforce } \\
\text { development }\end{array}$ & & $+\dagger$ & & $-*$ & $+\dagger$ \\
\hline Recreational hobby & & $+\dagger$ & & & $-*$ \\
\hline Community-building & $+\dagger$ & $+\dagger$ & & & $-*$ \\
\hline Public health / Nutrition & $+\dagger$ & & & $-\dagger$ & \\
\hline Therapeutic / Rehabilitation & & & & & $-\dagger$ \\
\hline Education - Children / Youth & & & $+*$ & $+\dagger$ & $-\dagger$ \\
\hline Education - Adults & & & & $-*$ & \\
\hline Sustainability & & $+*$ & & & $+\dagger$ \\
\hline Food quality / fresh food & & & & $-\dagger$ & \\
\hline $\begin{array}{l}\text { Environmental / } \\
\text { agroecological concerns }\end{array}$ & & & & $+\dagger$ & $+*$ \\
\hline Food security & $+*$ & & & & \\
\hline Food justice & $-{ }^{*}$ & $+*$ & & & \\
\hline Food sovereignty & $-\dagger$ & & & & \\
\hline Social justice & & $+\dagger$ & & & \\
\hline $\begin{array}{l}\text { Alternative economy / } \\
\text { non- or anti-capitalist exchange }\end{array}$ & & & $-*$ & & $+* *$ \\
\hline Faith-based / Spiritual & & $+\dagger$ & & & \\
\hline
\end{tabular}

$* * *$ indicates significance at $\mathrm{p}<0.0001 ; * *$ at $\mathrm{p}<0.01 ; *$ at $\mathrm{p}<0.05 ; \dagger$ at $\mathrm{p}<0.10$

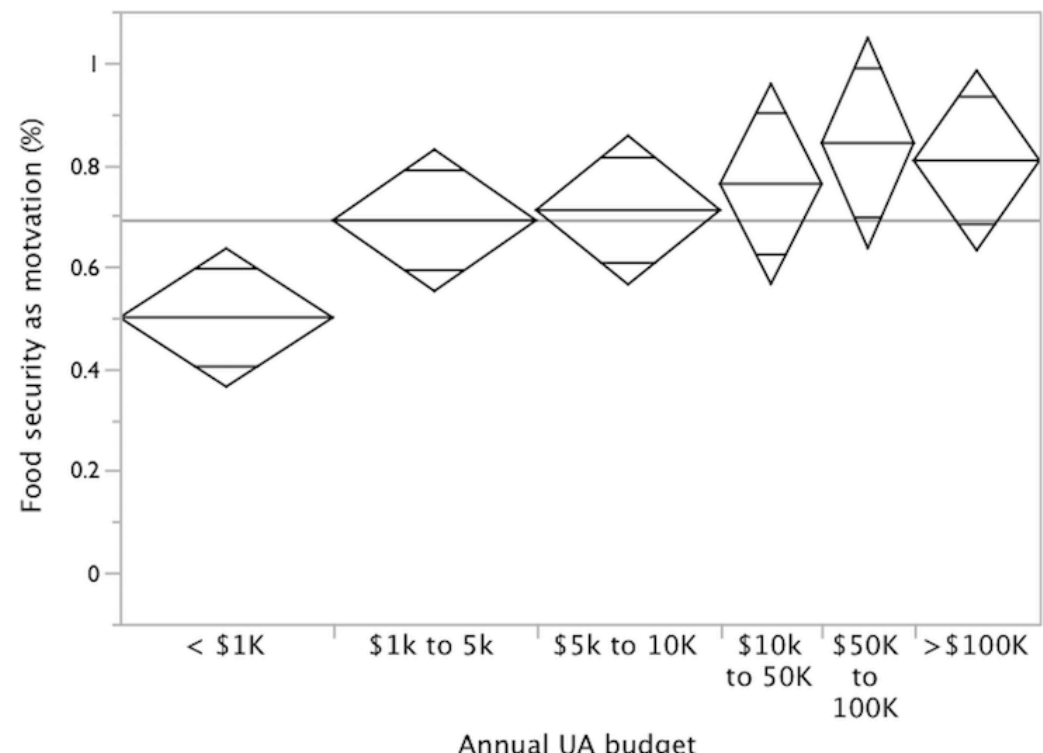

Fig 5 Food security as a primary motivation, disaggregated by organizational size as measured by annual UA budget. The center-line of each diamond represent each group's mean, while the vertical span represents its confidence interval (95\%). Diamond width is proportional to sample size. The single horizontal line (light grey) is the grand mean: $68 \%$ of respondents cited food security as a motivation. 
Indeed, for sustainability to serve as a motivation for most UA business owners suggests that it is a relatively "safe" concept that implies reform by working within existing politicaleconomic structures. Similarly, for large organizations to adopt it implies the availability of public and private funding available to support such work. Referring to the term as a "master signifier" (Davidson 2010) or "an empty word [that] allows it to contain a conflicting range of narratives under one label" (Gunder 2006, 211), critics have demonstrated how "sustainability" as an organizing concept has become increasingly depoliticized insofar as it can refer to many different things depending on the context of its use and the interpretation of its users. This may be precisely why the term is so widespread among UA practitioners.

The concept of "food security" is similarly broad, and is "embedded in dominant technocratic, neoliberal development discourses emphasizing increases in production and measurable supply and demand and is aligned with transnational agribusiness and institutions of governance at the national and international scales" (Jarosz 2014, 169-170). ${ }^{6}$ Progressive and radical food systems activists have opted to use other terms instead (e.g., community food security, food justice, food sovereignty) to underscore the importance of more bottom-up approaches to food security (Gottlieb and Joshi 2010; Wittman et al. 2012). Moreover, the focus in the Sustainable Development frame on providing access to fresh and nutritious food suggests an approach to improving public health that does not necessitate the radical disruption of social and economic structures. As Gunder $(2006,214)$ notes, "This discourse is particularly attractive for our existing institutions of state and governance because it continues to engage and even privilege the capital imperative of unbounded growth or at least give economic growth equal value to that of the social and the environmental." Within the context of this frame, selfsufficiency would therefore seem to channel the neoliberal discourse of personal responsibility which critics argue has depoliticized alternative food practices such as UA (Pudup 2008; Weissman 2015).

The Educational frame

Much like the Sustainable Development frame discussed above, the cluster of motivations that we call the Educational frame emphasizes all three axes of concern, but with slightly less emphasis on profitability. Education of either children or adults was a primary motivation for nearly $80 \%$ of organizations responding to our survey, and for over half of all businesses, with governmental agencies and NGOs significantly more likely than other organizational types to identify youth education as primary a motivation $(p<0.05)$. This is not surprising given that UA and education have been closely aligned for more than a century. Bassett (1981) and Lawson (2005) describe how UA was used as a way to instill particular cultural values in participants. For school children, this meant learning how to be good workers. For immigrants, the emphasis was similar, but with the additional goals of expediting assimilation, not only to add to the great American Melting Pot, but also to temper the communist and anarchist organizing that had traction in immigrant communities. In Canada, First Nations youth were taught agriculture in residential schools as a means of "civilizing" the indigenous culture and thereby consolidating the colonial project (Miller 1996). In the latter part of the 20th century, the educational orientation of UA programs was perhaps less about industry, labor, and thrift, and more on environment and nutrition. Education for adults was supported by

\footnotetext{
${ }^{6}$ The international agri-food corporation Monsanto, for example, states that its mission is to "make agriculture more productive and sustainable" (Monsanto 2015).
} 
federal Department of Agriculture programs, notably the Master Gardener programs which were launched in 1972, and school gardens blossomed across the country with the help of federal and state programs focused on nutrition education for youth (Lawson 2005).

Policymakers have expressed that underscoring UA's educational benefits is often the most compelling way to garner municipal support for UA projects (McClintock and Simpson 2016), which may further help to explain why the popularity of garden-based education has persisted. Illustrating this trend in our survey, larger organizations (both in terms of staff size and budget) more frequently cited youth education as a primary motivation (see Table 4). Organizations with youth education as a primary motivation received most of their funding from corporate and individual donations over governmental or foundation grants, while those focusing on adult education were less likely to depend on individual donations than other funding sources.

Educational goals are often explicitly environmental, fostering what some scholars have referred to as "urban environmental citizenship" (Light 2003; Baker 2005; Travaline and Hunold 2010). For example, one program surveyed "fosters ecological stewardship among middle school students ... by facilitating hands-on learning to explain the delicate balance, or imbalance, of urban ecosystems" (\#171, Washington, DC). Another educational organization explains, "When the children are growing their own food, learning to love the plants, the soil, the worms, the sun, etc., they are fully nourished \& become strong caretakers of the Earth" (\#21, Portland).

Many respondents see exposure to food production as central to this process of fostering a connection to nature. Motivated by "the need for children to be exposed to where their food comes from and to introduce them to new foods that they have grown themselves" (\#116, school, Washougal, WA), they view gardens as a place "where the connection with food and soil is demonstrated" (\#82, NGO, Hayward, CA) and where one can learn through "active, outdoor, community-integrated work connecting people to food and as a result, their inner \& outer environments" (\#117, NGO, Vancouver, BC). For these respondents, gardens are important sites for "rekindling connection/knowledge of how to grow food and where food comes from" (\#38, university, San Francisco). As one student group in Seattle explained, an understanding of where food comes from is augmented as UA "reconnect[s] the campus and greater community to the sources of their food ... and raise[s] awareness about the environmental impacts of sourcing methods" (\#182).

Concerns with reconnecting children with the food system are also frequently interconnected with concerns over health. In the words of a NGO in Syracuse, New York, "Many inner-city children have no understanding of agriculture or where food originates. Additionally, there is a need for nutritional education to reduce obesity and other health issues that plague the minority communities" (\#177). Similarly, a Los Angeles area community group notes, "many people do not know what healthy eating is or how to prepare the food that they grow" (\#166, Hermosa Beach, CA). Education, for many respondents, will ostensibly lead to better food choices: "We also believe in teaching people where their food comes from so that they can make educated decisions about their diet and nutrition. This includes both adults and children" (\#51, NGO, Denver). Such discourse fits with that identified by critical scholars who point to a particular kind of neoliberal subject formation associated with UA projects, where structural barriers to healthy eating are elided by discourse about healthy choices and personal responsibility (Pudup 2008; Weissman 2015). Moreover, critics argue that such an approach can perpetuate oppressive-and often racialized-missionary-like approaches driven by a patronizing refrain of "if they only knew..." (Guthman 2008; Ramírez 2015). 
Finally, some UA projects invoke the Educational frame simply by "cultivating awareness" (\#241, NGO, Victoria, BC) outside of an institutional setting, emphasizing their ability to "lead by example and inspire people to make healthier and more sustainable food choices" (\#182, university, Seattle). Indeed, raising awareness is one of the central mechanisms through which urban agriculturalists envision how their own localized actions will have much broader impacts. This catholic understanding of education thus likely leads to its appearance as a motivation alongside many others outside of traditional institutional settings.

\section{The Eco-Centric frame}

Like the Sustainable Development and Entrepreneurial frames described above, practitioners who subscribe to the Eco-Centric frame are motivated by sustainability, but tend to place a greater emphasis on environmental health and wellbeing over and above the social or economic components of sustainability. Echoing claims made by scholars of ecosystem services, some Eco-Centrists make a case for UA's contribution to urban biodiversity by creating green spaces and habitat for pollinators (Barthel et al., 2010; Andersson et al., 2007; Colding et al., 2006), while others emphasize the contribution that it makes to climate change mitigation and/or adaptability (Dixon et al., 2009). This frame has its roots in the environmental movements arising in the wake of Rachel Carson's Silent Spring in 1962 (Gottlieb 1993), and its lineage can be traced through the emergence of fields of ecological restoration (Higgs 2003), deep ecology (Drengson and Inoue 1995), and agroecology (Altieri 1995; Gliessman 2000). Practitioners of permaculture design who aspire to create abundant human habitats that are fully integrated into ecological cycles also fit comfortably into the Eco-Centric frame (Ferguson and Lovell 2013; Hathaway 2015).

Indeed, environmental / agro-ecological concern was one of most common drivers indicated by our survey respondents ( $71 \%$ of all respondents, including $88 \%$ of all businesses), and was more common among organizations dependent on sales and individual donations. Ecological restoration/native habitat was far less common, but nevertheless a motivation for nearly a third of respondents. Practitioners frequently cited the reduction of the distance that food has to travel from producer to consumer as a key contribution of UA. Despite growing skepticism about the actual environmental impact of reducing "food miles" (Weber and Matthews 2008; Coley et al. 2013), Eco-Centric discourse is common among UA practitioners who view their efforts as "shortening the distance food travels to folks" (\#44, Raleigh, NC). Many contend that reducing "the distance that food travels from field to plate" (\#22, Portland) aids in the reduction of carbon footprint, which in turn mitigates climate change, as expressed by one Toronto-based respondent who expressed the goal is to "lessen greenhouse gas emissions by eliminating food transportation" (\#42). Similarly, a Portland community group's motivation is "promoting less carbon impact on the planet by producing/harvesting food locally" (\#34).

Some respondents emphasized that by contributing to a robust ecology, UA gives rise to a resilient society, able to successfully adapt to a shifting climate. One Florida governmental organization is explicit about these challenges, and works "to build a more resilient community in the face of climate change threats and rising energy costs" (\#134, Gainesville, FL). This widespread embrace of resilience discourse by respondents follows the growing momentum among environmental policymakers and planners emphasizing strategies to adapt to climate or economic-related shocks and changes, a concept that, like sustainability, has come under scrutiny for its lack of specificity (Carpenter et al. 2001; Cretney 2014) and its inherent acceptance of 
adaptation as a response to global environmental change rather than serving efforts to mitigate the underlying causes (MacKinnon and Derickson 2013). In most cases, "resilience" is employed rather abstractly, with little specification "of what to what" (Carpenter et al. 2001).

\section{The DIY Secessionist frame}

In a seminal article, Kloppenberg et al. (1996, 38) describe what they refer to as "secession" or "disengagement from the existing food system and especially from the narrow commodity and market relations on which it is based." They describe the principle of secession as "based on a strategic preference for withdrawing and/or creating alternatives to the dominant system rather than challenging it directly" (ibid.). Many who are motivated by what we call the DIY Secessionist frame share an aspiration for structural change with the Radical frame we describe below; however, they pursue this transformation with a strategy of severing of ties with the dominant agro-industrial food system and building up alternatives.

Strands of this approach can be traced from the utopian socialists such as Robert Owens and Charles Fourier and the voluntary simplicity of Henry David Thoreau of the early and mid19 th century, to the Garden City movement of the early 20th century and later back-to-the-land countercultural movements of the 1960s and 70s (Harvey 2000; Pinder 2005; Fairfax et al. 2012). ${ }^{7}$ The recent (re)emergence of craft or artisanal production (and related valorization manual labor) have further fueled the embrace of UA (Carfagna et al. 2014), as has a sense that UA can serve as a buffer against economic uncertainty. Historically, UA's popularity has swelled in times of economic crisis (Lawson 2005; McClintock 2010), including following the economic crash of 2008 (Tavernise 2011).

Along our three axes of concern, the DIY Secessionist frame privileges environmental over social concerns, while ambivalent in regards to economic profitability. Central to this frame is the motivation to create autonomous forms of organization that do not depend on the dominant political-economic structures, hence our use of "DIY" or "do-it-yourself". Over 40\% of organizations and half of businesses surveyed indicated self-sufficiency as a primary motivation; a "desire to produce our own food" (\#94, NGO, Seattle), to "feed ourselves where we live and build more rooted community in the process" (\#265, NGO, Portland), and "to have a connection to nature, to grow our own food, to come together as a community" (\#203, CBO, New York) were common. One Portland business respondent noted, "In reclaiming our ability to grow our own food ... we are able to act independently of large-scale corporations and capitalistic business models that actively destroy intact ecologies in the name of profit" (\#36).

The DIY Secessionist frame seems to ascribe a different meaning to self-sufficiency than does the Sustainable Development frame described above. Within the DIY Secessionist frame, self-sufficiency is less defined in terms of personal responsibility and more in terms of community self-reliance and self-determination, not unlike the foundational ideals of food sovereignty as described above. To this end, many are explicit about a motivation to operate

\footnotetext{
${ }^{7}$ The DIY Secessionist frame appears to be distinct from a more survivalist approach - but the boundary does seem blurry - where "preppers" are motivated to grow and store food in order to insulate themselves from imminent and apocalyptic societal collapse. Whereas DIY Secessionists believe that they are modeling new forms of social relations that will ultimately nourish and support transformative structural change, preppers tend to be more interested in their individual self-preservation after the looming chaos ensues. Very few of the businesses or organizations that we surveyed espoused this catastrophist worldview, and we suspect that such an outlook is more common among individual practitioners of UA more than among collaborative groups. Future scholarship might try to better tease out the oft-politicized values (e.g., libertarian, communitarian) that may be conflated in this frame.
} 
outside of the dominant market logic of capitalism, placing production under the control of the communities it serves.

Similarly, DIY practitioners understand their work as a means to create spaces that operate as commons, shielded from the capitalist economy in certain respects, that allow alternate forms of economic exchange and social relations to emerge. More than a third of survey respondents cited reclamation of the commons as a primary motivation; it was also the variable with the highest factor loading. A Portland collective describes such a reclamation as "a reorganization to the distribution of land and make its usage (primarily food production) available to all" (\#4). An organization working in metro-Montreal describes the collective garden (jardin collectif) model common in the city: "The land is cultivated by the group, without [individual] parcel divisions. Harvested products are distributed in proportion to volunteer hours worked" (\#108, Longueuil, QC). A New York City NGO simply states, "We believe in the commons" (\#125).

As decommodified spaces of production, free from ownership and control by a private landowner, the commons stand as a quintessential symbol of the anti-capitalist orientation described above, drawing both on anarchist ideals of mutual aid and cooperation (Kropotkin 1902; Heynen 2010; Purcell and Tyman 2014) and a Utopian belief that such places are physically realizable in space and time (Harvey 2000; Pinder 2005). Taking their cues from the radical back-to-the-land countercultural communards, urban community garden activists in the 1970s pushed back against the logics of capitalist property regimes by asserting usufruct rights and managing land communally (Lawson 2005). With neoliberal reinvestment in the urban core over the past few decades and consequent increase in market value of vacant lots, many of these gardens have been destroyed or threatened with removal. Community garden activists fighting displacement regularly invoke the commons in their struggles, arguing for the primacy of use value over exchange value (Schmelzkopf 2002; Staeheli et al. 2002; Eizenberg 2012).

Over the past few years, scholars and advocates of UA have turned their attention to identifying new "urban commons" (Colding and Barthel 2013; Tornaghi 2014), including the vast number of vacant lots or otherwise "underutilized" urban land, public and private, calculating the potential productive capacity of such spaces (Colasanti and Hamm 2010; MacRae et al. 2010; Grewal and Grewal 2012; McClintock et al. 2013). In general, CBOs identified reclamation of commons as a primary motivation more than other types of organizations $(\mathrm{p}<0.05)$, and respondents in the Northeast/Mid-Atlantic, OR/WA, and English-speaking Canada, more than other geographic areas. It may be that the high profile destruction of community gardens in New York City (Schmelzkopf 2002; Staeheli et al. 2002; Smith and Kurtz 2003; Eizenberg 2012) explain the prevalence of this motivation among Northeastern respondents, while an appeal to the commons has long informed a bioregional secessionist imaginary in Cascadia - Oregon, Washington, and BC - since at least the 1975 publication of Ernest Callenbach's Ecotopia (McClintock and Simpson 2016). ${ }^{8}$ In both cases, the appeals to commoning may signal the regional prevalence of such discourse, where practitioners have either internalized these ideals or simply frame their work in such a way to gain political traction and the support of funders and the public for their efforts.

Given the need to collectively manage the commons, a commitment to building community also figures prominently in the DIY Secessionist frame. The tension between a universally accessible commons and one that is open only to those who might steward it according to a particular set of values has long roiled discussions over common pool resource

\footnotetext{
${ }^{8}$ Responses from BC comprise a large portion of our "Other Canada" analytical category (see Table 1).
} 
management, "right to the city" movements, and community development by raising sticky questions such as: Whose commons? Whose right to the city? Which community? Collective management requires the negotiation of access and of what constitutes acceptable practices, as well as the policing of behavior to ensure that these agreements are upheld (Harvey 2003; Marcuse 2009). Secession therefore always begs the question of who will take part in this separate commons-based alternative economy and whether or not such efforts constitute a defensive localism (DuPuis and Goodman 2005) or a "critical agrarianism" (Carlisle 2014) that is more reflexive about its imbrication within historical and contemporary processes of exclusion.

The Radical frame

What we identify as the Radical frame is a cluster of motivations that emphasize UA's contribution to social justice, food justice, food sovereignty, and anti-capitalist exchange, privileging social concerns over environmental concerns and profit. Holt-Giménez and Shattuck (2011) claim that food movements can broadly be characterized as either progressive or radical, where radical movements call for systemic changes to capitalist and imperialist structures such as property regimes and global markets. Urban agriculturalists guided by this frame-which is well documented in recent UA scholarship - are motivated to grow food locally as a means of wresting the means of production from the "corporate food regime" (McMichael 2009). They are further concerned with the ways that the dominant industrial agri-food system shores up and/or exacerbates existing forms of race-, class-, and gender-based oppression (Sbicca 2012; Bradley and Galt 2014; Passidomo 2014; Ramírez 2015). Some scholars have characterized UA as a practice that resists capital and property ownership by asserting a Lefebvrean "right to the city" that challenges dominant approaches to land use and urban planning (Schmelzkopf 2002; Staeheli et al. 2002; Smith and Kurtz 2003; Eizenberg 2012; Purcell and Tyman 2014).

Explicit attention to underlying structural inequities lies at the heart of the Radical frame. Nearly a quarter of respondents overall indicated that their endeavors are non- or anti-capitalist, or a means of creating an alternative economy. An Oakland-based organization invokes this anticapitalist logic, for example, by claiming that "UA that allows us to re-build a food system that works for people not profit" (\#101). Moreover, many respondents mentioned justice in their description of what motivates their organizations to engage in UA. Several groups expressed this in simple terms: "We are committed to developing a sustainable and just community food system" (\#112, NGO, Binghamton, NY). Roughly 40\% of respondents framed their motivations as food sovereignty, the freedom for communities to "create their own food destiny" (\#155, $\mathrm{CBO}$, Cleveland). For some, the self-determination associated with food sovereignty extends beyond simply production and distribution, but also to governance: "We value operating and self-governance structures and processes that are guided by transparency, honesty, diversity, mutual respect, openness, on-going evaluation, celebration, and a commitment to stakeholder participation" (\#240, community land trust, Providence, RI).

Many organizations espousing the Radical frame are explicit about the need to decommodify food. One Canadian group, for example, perceives the practice of UA as "challenging individualist, consumerist approaches to food and space as commodities" and as "fostering an approach to food sovereignty based in mutual aid" (\#226, Powell River, BC). Similarly, another Montreal organization is motivated by a goal of producing and distributing a 
quarter of the city's fruits and vegetables through such "local networks of social economy" (\#52). ${ }^{9}$ Community-based organizations were most likely to invoke such motivations $(\mathrm{p}<0.01)$.

School-based UA organizations, on the other hand, invoked food justice $(p<0.10)$ and social justice $(p<0.05)$ more often than did other organizational types, likely due to dominance of activists in colleges and universities. Among the motivations comprising the Radical frame, however, there was significant geographic variation (see Fig. 6). Social justice was more frequently a motivation for respondents from Northeast/mid-Atlantic states and California, whereas food justice was dominant among California respondents. Food justice is particularly resonant discourse in the Bay Area, with $75 \%$ of organizations of Bay Area respondents identifying it as a primary motivation. This is likely due to a long history of radical food activism in the metropolis, dating back to the Black Panthers and SF Diggers, later reinvigorated by a vibrant environmental justice movement (Alkon 2012; Fairfax et al. 2012; McClintock 2011).



Fig 6 Percentage of respondents indicating food justice, social justice, and food sovereignty as a primary motivation, by geographic location

Interestingly, US organizations cited food justice more often than did their Canadian counterparts, with roughly a half of US respondents employing the term as compared to slightly more than a third from Montreal and about $40 \%$ of other Canadian organizations. It is possible that the less frequent use of the term in Canada arises from that country's more expansive social safety net. Conversely, in the US, the frequency of food justice is likely linked to the long history of community organizing against racial discrimination and the stripping away of the Keynesian welfare state. Indeed, the food justice movement in the US has roots in radical civil rights and EJ struggles (Gottlieb and Joshi 2010; Alkon and Agyeman 2011), while much Canadian

\footnotetext{
${ }^{9}$ All quotes from Quebec respondents are the authors' translation from the original response in French.
} 
scholarship and food justice activism, on the other hand, has focused on food access for Indigenous communities, and more often employs lenses of decolonization and food sovereignty (Rudolph and McLachlan 2013; Desmarais and Wittman 2014). Recent scholarship on the origins of food sovereignty sheds light on some of the nuances distinguishing this concept from that of food justice. While food justice is often framed in terms of distributional equity, food sovereignty more explicitly emphasizes control over the means of production (Alkon and Mares 2012; Block et al. 2012; Jarosz 2014; Roman-Alcalá 2015). White (2011, p. 408), for example, describes how the Detroit Black Community Food Security Network advocates farming as a strategy for African Americans to "improve and strengthen the community's local economy" while "building a sense of justice, equity, and self-determination". These objectives are not at odds and they both fit comfortably within the Radical frame, however our survey results suggest that some groups tend to emphasize one more than the other.

As with food justice, there was considerable regional variation in food sovereignty as a motivation. Montreal respondents resoundingly framed their work in terms of food sovereignty (souveraineté alimentaire) and food security (sécurité alimentaire), while food justice (justice alimentaire) is much less frequently used to frame UA efforts by respondents in francophone Canada. ${ }^{10}$ Since the "Quiet Revolution" of the 1960s, the term "sovereignty" has held a powerful political valence in Quebec (Mills 2010), likely undergirding its frequent use in relation to food. Additionally, the Government of Quebec recently issued a Food Sovereignty Plan that included discussion of the role of UA (Boily 2012), and the City of Montreal's recent participatory process to develop UA policy frequently employed both food security and food sovereignty framing (Ville de Montréal 2012). Such official discourse invoking food sovereignty implicitly (and at times explicitly) taps into more widely held culturally and/or politically nationalist ideologies tangentially related to food. As a result, food sovereignty for Québecois respondents may actually mean something quite different than for others, radical nevertheless.

Finally, funding appears also to play a role in the embrace of the Radical frame, as well as the specific motivations therein. Organizations invoking food justice and social justice as primary motivations tended to receive the majority of their funding from private foundation grants. Those invoking food justice and food sovereignty were also less likely to operate using government funding sources. These trends suggest the political sensitivity of such terms, in contrast to the relative freedom of foundations to fund more explicitly equity-oriented projects.

\section{Conclusions}

As our results of our study demonstrate, a wide range of objectives shape how urban agriculturalists perceive their practice. Political orientations and discourses of practitioners differ across geographies, as well as in accordance with organizational type, size, and source of funding. As we have seen, some practitioners are motivated by a desire to work within existing political-economic structures, whereas others seek autonomy by removing themselves from these structures, and others still seek radical transformation through direct contestation. Some groups emphasize transformation of social and economic structures, whereas others emphasize the transformation of humans' relationship to the non-human world. Moreover, our survey reveals that it is not only the political objectives of UA practitioners that differ, but also their strategies. For instance, some employ UA as a way of educating people about social and economic change,

\footnotetext{
${ }^{10}$ Participant observation and informal and semi-structured interviews conducted in Montreal in 2012, 2013 and 2015 by the first author substantiate these results.
} 
whereas others practice UA as a means of right livelihood that will transform the economy, or to model social and economic alternatives.

The motivations of UA practitioners are inherently subjective assessments of UA's assumed benefits rather than objective evaluations of its actual impact. But, as different motivational frames of UA practitioners come into focus - why urban agriculturalists do the work that they do and what impacts they believe they have - it becomes clear that UA's origins are manifold, making it difficult to make normative claims about UA's radical or neoliberal nature. Rather, UA is a contested field, rife with contradictory aspirations, motivations, and outcomes. Some organizations may challenge dominant political economic structures, while others have no intention of doing so. In most cases however, UA practitioners challenge specific aspects of the status quo while reinforcing others, and even inadvertently reproducing neoliberal logics or structures of racial oppression (Pudup 2008; Sbicca 2012; Ramírez 2015; Reynolds 2015). In short, the multiple functions of UA are highly contextual and uneven, as are claims to its ability to foster or advance social change.

Despite this variability we can identify some patterns in the messiness. Our rough typology of motivational frames-which emerged not only from statistical groupings obtained via quantitative PCA, but also through our qualitative analysis of open-ended responses and our engagement with existing literature on UA's benefits and motivations - not only elucidates the motivations giving rise to UA practice in Canada and the US as others have, but also the ways in which they tend to overlap and cluster, as well as vary across geographies, organizational types, and funding contexts. Moreover, we emphasize the relationship of particular motivational frames to specific institutional configurations, as well as to larger-scale cultural trends and political economic contexts.

It is important to note that given the overall sample size, geographic response bias, and likely underrepresentation of non-English-speaking and French-speaking organizations and businesses, our results are statistically representative only of our survey respondents and are not generalizable to all organizations and businesses engaging in UA in Canada and the US. Indeed, the population of respondents only begins to scratch the surface of a vast and diverse field of UA businesses and organizations. As with all exercises in categorization, the boundaries of these motivational frames remain blurry at best. In some moments they overlap, at other moments they come into conflict, and at other times still they fail to capture those outliers resisting clear classification.

Given the nature of extensive studies, our survey and analysis surely misses some of the nuances of particular local struggles or discourses that influence UA practitioners in a specific place. At the organizational level, power differentials between staff members, for example, might shape the motivational frames and UA practices. Furthermore, while we did not find substantive qualitative differences in the eight cases where we received multiple responses from a single organization, it is nevertheless important to consider how a respondent's position might influence the extent to which they embrace a particular frame or employ the language used in the group's mission statement. Finally, unless explicitly stated by the respondent, it was unclear whether the motivations were those of the organization or of the respondents themselves. Further research is needed to gain a better understanding how these motivational frames are ultimately put into practice — or not — via organizational dynamics and day-to-day operations.

With these caveats in mind, our study nevertheless reveals important trends and patterns that offer rich opportunities for further inquiry. Responses from 251 UA groups in 84 cities across the two countries allow for extensive analysis of what drives UA among these 
respondents, thus contributing to recent work that foregrounds the wide-ranging practices and orientations that fall within the broad scope of UA (Drake and Lawson 2014a; McClintock 2014; Taylor and Lovell 2014; Pourias et al. 2015), thereby challenging monolithic characterizations about the impact of UA or its drivers. To this end, this research more specifically adds measured insight to debates as to whether UA is an inherently radical political practice.

Moreover, the motivational frames emerging from our methodology may be valuable for future research on UA in that they can serve as an analytical framework that can complement the in-depth, qualitative work needed to grasp the difference between intentions and outcomes, while helping link historically and geographically specific insights to wider social and political economic processes. Future work might use intensive, qualitative methods to explore the validity of these motivational frames in specific cases, or replicate our study to include a broader set of cities in the Global North - in Europe or Oceania, for example - or to determine what frames predominate among UA practice in the Global South.

In addition to the theoretical contributions that our research makes to the study of UA, it may also be of practical interest to both UA practitioners and policymakers. For practitioners, our framework might help organizations place their approach to UA in relation to others, inspiring critical self-reflection on how they frame their work, with an eye to identifying possible blind spots or limitations. Similarly, given the growing trend among North American municipalities to promote and/or regulate UA, we hope that our work might encourage policymakers to consider the presumed motives and associated outcomes of UA initiatives, as policies could either benefit or obstruct UA practitioners depending on which motivational frame guides their efforts. Officials often have particular types of UA in mind as they develop UA policy, and policies presuming UA to be radical or anti-establishment might look quite different than policies developed to foster entrepreneurial or sustainable development enterprises.

To conclude, the political stakes and consequences of UA are not determined in advance, but rather play out in practice on the ground. Consequently, it is imperative that UA researchers consider the motivations, objectives, perspectives, and struggles of practitioners in their own words in order to understand the real world benefits and impacts of food production in urban environments. Identifying how practitioners stack functions and situate their work within motivational frames is a first step in helping to differentiate the diverse-and often contradictory - efforts transforming urban food environments across North America.

\section{Acknowledgements}

The authors are extremely grateful to all of the respondents for taking the time to complete the survey. They also wish to thank Alexandrine Boudreault-Fournier for her comments and proofreading of the French survey, Taren Evans for her assistance in identifying potential survey respondents, and Anthony Levenda for assistance with coding responses. The comments of three anonymous reviewers were particularly useful. This research was funded in part by a PSU Faculty Enhancement Grant. 


\section{References}

Alkon, A. H. 2012. Black, white, and green: farmers markets, race, and the green economy. Athens, GA: University of Georgia Press.

Alkon, A. H., and J. Agyeman eds. 2011. Cultivating food justice: race, class, and sustainability. Cambridge, MA: The MIT Press.

Alkon, A. H., and T. Mares. 2012. Food sovereignty in US food movements: radical visions and neoliberal constraints. Agriculture and Human Values 29(3):347-359.

Altieri, M. A. 1995. Agroecology: the science of sustainable agriculture. Boulder, CO: Westview Press.

Baker, L. E. 2005. Tending cultural landscapes and food citizenship in Toronto's community gardens. Geographical Review 94(3):305-325.

Bassett, T. J. 1981. Reaping on the margins: a century of community gardening in America. Landscape 25(2):1-8.

Bettencourt-McCarthy, W. 2013. Protesters want Queen's Park to rethink food policy. Torontoist, 2 May. http://torontoist.com/2013/05/protesters-want-queens-park-to-rethink-food-policy/. Accessed 16 Jan 2017.

Blecha, J., and H. Leitner. 2013. Reimagining the food system, the economy, and urban life: new urban chickenkeepers in US cities. Urban Geography 35(1):86-108.

Block, D., N. Chávez, E. Allen, and D. Ramirez. 2012. Food sovereignty, urban food access, and food activism: contemplating the connections through examples from Chicago. Agriculture and Human Values 29(2):203215.

Boily, M.-E. 2012. L'agriculture urbaine et periurbaine au Québec. Quebec City: Gouvernement du Québec, Ministère de l'Agriculture, des Pêcheries et de l'Alimentation. http://www.mapaq.gouv.qc.ca/fr/Publications/Agricultureurbaineetperiurbaine.pdf. Accessed 10 Mar 2017.

Bradley, K., and R. E. Galt. 2014. Practicing food justice at Dig Deep Farms \& Produce, East Bay Area, California: self-determination as a guiding value and intersections with foodie logics. Local Environment 19(2):172186.

Brinkley, C., and D. Vitiello. 2014. From farm to nuisance animal agriculture and the rise of planning regulation. Journal of Planning History 13(2):113-135.

Buehler, D., and R. Junge. 2016. Global Trends and Current Status of Commercial Urban Rooftop Farming. Sustainability 8 (11):1108-1126.

Burns, G. 2016. Documentary explores Hantz Farms "land grab” in Detroit. MLive.com, 24 July. http://www.mlive.com/news/detroit/index.ssf/2016/07/land_grab_documentary_looks_at.html. Accessed 16 Jan 2017.

Campbell, S. 1996. Green cities, growing cities, just cities? urban planning and the contradictions of sustainable development. Journal of the American Planning Association 62(3):296-312.

Carfagna, L. B., E. A. Dubois, C. Fitzmaurice, M. Y. Ouimette, J. B. Schor, M. Willis, and T. Laidley. 2014. An emerging eco-habitus: the reconfiguration of high cultural capital practices among ethical consumers. Journal of Consumer Culture 14(2):158-178.

Carlisle, L. 2014. Critical agrarianism. Renewable Agriculture and Food Systems 29(2):135-145.

Carolan, M., and J. Hale. 2016. "Growing" communities with urban agriculture: generating value above and below ground. Community Development 47(4):530-545.

Carpenter, S., B. Walker, J. M. Anderies, and N. Abel. 2001. From metaphor to measurement: resilience of what to what? Ecosystems 4(8):765-781.

Christensen, R. 2007. SPIN farming: improving revenues on sub-acre plots. Urban Agriculture Magazine 19:25-26.

Colasanti, K., and M. Hamm. 2010. Assessing the local food supply capacity of Detroit, Michigan. Journal of Agriculture, Food Systems, and Community Development 1(2):41-58.

Colding, J., and S. Barthel. 2013. The potential of "urban green commons" in the resilience building of cities. Ecological Economics 86:156-166.

Coley, D., M. Winter, and M. Howard. 2013. National and international food distribution: do food miles really matter? In Sustainable food processing, eds. B. K. Tiwari, T. Norton, and N. M. Holden, 497-520. New York: John Wiley \& Sons, Ltd.

Cretney, R. 2014. Resilience for whom? emerging critical geographies of socio-ecological resilience. Geography Compass 8(9):627-640.

Davidson, M. 2010. Sustainability as ideological praxis: the acting out of planning's master-signifier. City 14(4):390-405. 
Desmarais, A. A., and H. Wittman. 2014. Farmers, foodies and First Nations: getting to food sovereignty in Canada. Journal of Peasant Studies 41(6):1153-1173.

Drake, L., and L. J. Lawson. 2014a. Results of a US and Canada community garden survey: shared challenges in garden management amid diverse geographical and organizational contexts. Agriculture and Human Values 32(2):241-254.

Drake, L., and L. J. Lawson. 2014b. Validating verdancy or vacancy? The relationship of community gardens and vacant lands in the U.S. Cities 40(B):133-142.

Draper, C., and D. Freedman. 2010. Review and analysis of the benefits, purposes, and motivations associated with community gardening in the United States. Journal of Community Practice 18(4):458-492.

Drengson, A., and Y. Inoue eds. 1995. The deep ecology movement: an introductory anthology. Berkeley: North Atlantic Books.

DuPuis, E. M., and D. Goodman. 2005. Should we go "home" to eat?: toward a reflexive politics of localism. Journal of Rural Studies 21(3):359-371.

Eizenberg, E. 2012. Actually existing commons: three moments of space of community gardens in New York City. Antipode 44(3):764-782.

Fairfax, S. K., L. N. Dyble, G. T. Guthey, L. Gwin, M. Moore, and J. Sokolove. 2012. California cuisine and just food. Cambridge, MA: The MIT Press.

Ferguson, R. S., and S. T. Lovell. 2013. Permaculture for agroecology: design, movement, practice, and worldview: a review. Agronomy for Sustainable Development 34(2):251-274.

Gliessman, S. R. 2000. Agroecology: ecological processes in sustainable agriculture. Boca Raton, FL: CRC Press.

Goffman, E. 1974. Frame analysis: an essay on the organization of experience. Boston: Northeastern University Press.

Gottlieb, R. 1993. Forcing the spring: the transformation of the American environmental movement. Washington: Island Press.

Gottlieb, R., and A. Joshi. 2010. Food justice. Cambridge, MA: The MIT Press.

Grewal, S. S., and P. S. Grewal. 2012. Can cities become self-reliant in food? Cities 29(1):1-11.

Guitart, D., C. Pickering, and J. Byrne. 2012. Past results and future directions in urban community gardens research. Urban Forestry \& Urban Greening 11(4):364-373.

Gunder, M. 2006. Sustainability: planning's saving grace or road to perdition? Journal of Planning Education and Research 26(2):208-221.

Guthman, J. 2008. "If they only knew": color blindness and universalism in California alternative food institutions. The Professional Geographer 60(3):387-397.

Harvey, D. 2000. Spaces of hope. Berkeley: University of California Press.

Harvey, D. 2003. The right to the city. International Journal of Urban and Regional Research 27(4):939-941.

Hathaway, M. D. 2015. Agroecology and permaculture: addressing key ecological problems by rethinking and redesigning agricultural systems. Journal of Environmental Studies and Sciences :1-12.

Heynen, N. 2010. Cooking up non-violent civil-disobedient direct action for the hungry: "Food Not Bombs" and the resurgence of radical democracy in the US. Urban Studies 47(6):1225-1240.

Higgs, E. 2003. Nature by design: people, natural process, and ecological restoration. Cambridge, MA: MIT Press.

Jarosz, L. 2014. Comparing food security and food sovereignty discourses. Dialogues in Human Geography 4(2):168-181.

Kaufman, J. L., and M. Bailkey. 2000. Farming inside cities: entrepreneurial urban agriculture in the United States. Cambridge, MA: Lincoln Institute of Land Policy.

Kloppenberg, J., J. Henrickson, and G. W. Stevenson. 1996. Coming into the foodshed. Agriculture and Human Values 13(3):33-42.

KLRU. 2015. Warrior and family support center healing gardens. Central Texas Gardener, 7 Nov. http://www.klru.org/ctg/episode/taking-care-of-trees/. Accessed 31 Jan 2017.

Kortright, R., and S. Wakefield. 2011. Edible backyards: a qualitative study of household food growing and its contributions to food security. Agriculture and Human Values 28(1):39-53.

Kroonenberg, P. M. 2004. Principal components analysis. In The SAGE encyclopedia of social science research methods, eds. M. S. Lewis-Beck, A. Bryman, and T. F. Liao. London: SAGE Publications. $\mathrm{http} / / /$ srmo.sagepub.com/view/the-sage-encyclopedia-of-social-science-research-methods/n748.xml. Accessed 2 Nov 2015.

Kropotkin, P. 1902. Mutual aid: a factor of evolution. London: William Heinemann.

Kulak, M., A. Graves, and J. Chatterton. 2013. Reducing greenhouse gas emissions with urban agriculture: a life cycle assessment perspective. Landscape and Urban Planning 111:68-78. 
Kurtz, H. E. 2003. Scale frames and counter-scale frames: constructing the problem of environmental injustice. Political Geography 22(8):887-916.

Lawson, L. J. 2005. City bountiful: a century of community gardening. Berkeley: University of California Press. Light, A. 2003. Urban ecological citizenship. Journal of Social Philosophy 34(1):44-63.

Lin, B. B., S. M. Philpott, and S. Jha. 2015. The future of urban agriculture and biodiversity-ecosystem services: challenges and next steps. Basic and Applied Ecology 16(3):189-201.

Lyson, H. C. 2014. Social structural location and vocabularies of participation: fostering a collective identity in urban agriculture activism. Rural Sociology 79(3):310-335.

MacKinnon, D., and K. D. Derickson. 2013. From resilience to resourcefulness: a critique of resilience policy and activism. Progress in Human Geography 37(2):253-270.

MacRae, R., E. Gallant, S. Patel, M. Michalak, M. Bunch, and S. Schaffner. 2010. Could Toronto provide 10\% of its fresh vegetable requirements from within its own boundaries? matching consumption requirements with growing spaces. Journal of Agriculture, Food Systems, and Community Development 1(2):105-127.

Marcuse, P. 2009. From critical urban theory to the right to the city. City 13(2):185-197.

Martin, D. G. 2003. "Place-framing" as place-making: constituting a neighborhood for organizing and activism. Annals of the Association of American Geographers 93(3):730-750.

McClintock, N. 2010. Why farm the city? Theorizing urban agriculture through a lens of metabolic rift. Cambridge Journal of Regions, Economy and Society 3(2):191-207.

McClintock, N. 2014. Radical, reformist, and garden-variety neoliberal: coming to terms with urban agriculture's contradictions. Local Environment 19(2):147-171.

McClintock, N., J. Cooper, and S. Khandeshi. 2013. Assessing the potential contribution of vacant land to urban vegetable production and consumption in Oakland, California. Landscape and Urban Planning 111:46-58.

McClintock, N., D. Mahmoudi, M. Simpson, and J. P. Santos. 2016. Socio-spatial differentiation in the Sustainable City: a mixed-methods assessment of residential gardens in metropolitan Portland, Oregon, USA.

Landscape and Urban Planning 148:1-16.

McClintock, N., and M. Simpson. 2014. A survey of urban agriculture organizations and businesses in the US \& Canada: preliminary results. Portland State University, Toulan School of Urban Studies and Planning. http://archives.pdx.edu/ds/psu/12615. Accessed 10 Mar 2017.

McClintock, N., and M. Simpson. 2016. Cultivating in Cascadia: urban agriculture policy and practice in Portland, Seattle, and Vancouver. In Cities of farmers: problems, possibilities and processes of producing food in cities, eds. J. Dawson and A. Morales,59-82. Iowa City: University of Iowa Press.

McMichael, P. 2009. A food regime geneaology. Journal of Peasant Studies 36(1):139-169.

Miller, J. R. 1996. Shingwauk's vision: a history of native residential schools. Toronto: University of Toronto Press.

Mills, S. 2010. The empire within: postcolonial thought and political activism in sixties Montreal. Montreal, QC and Kingston, ON: McGill-Queens University Press.

Monsanto. 2015. Our commitment to sustainable agriculture. http://www.monsanto.com/whoweare/pages/ourcommitment-to-sustainable-agriculture.aspx. Accessed 27 Oct 2015.

Moore, S. 2006. Forgotten roots of the Green City: subsistence gardening in Columbus, Ohio, 1900-1940. Urban Geography 27(2):174-192.

Mougeot, L. J. A. 2005. Agropolis: the social, political and environmental dimensions of urban agriculture. Ottawa: IDRC.

Nordh, H., K. T. Wiklund, and K. E. Koppang. 2016. Norwegian allotment gardens - a study of motives and benefits. Landscape Research 41(8):853-868.

Orsini, F., D. Gasperi, L. Marchetti, C. Piovene, S. Draghetti, S. Ramazzotti, G. Bazzocchi, and G. Gianquinto. 2014. Exploring the production capacity of rooftop gardens (RTGs) in urban agriculture: the potential impact on food and nutrition security, biodiversity and other ecosystem services in the city of Bologna. Food Security 6(6):781-792.

Passidomo, C. 2014. Whose right to (farm) the city? race and food justice activism in post-Katrina New Orleans. Agriculture and Human Values 31(3):385-396.

Pinder, D. 2005. Visions of the city: utopianism, power and politics in twentieth-century urbanism. New York: Routledge.

Portland City Council. 2009. Resolution No. 36699: Establish a Better Together Organic Garden at Portland City Hall to encourage the production of community-grown food and urge Portland and Multnomah County residents to assist hunger relief efforts by supporting the Plant a Row for the Hungry campaign. http://www.portlandonline.com/shared/cfm/image.cfm?id=275676. Accessed 10 Mar 2017. 
Pourias, J., C. Aubry, and E. Duchemin. 2016. Is food a motivation for urban gardeners? multifunctionality and the relative importance of the food function in urban collective gardens of Paris and Montreal. Agriculture and Human Values 33(2):257-273.

Pudup, M. 2008. It takes a garden: cultivating citizen-subjects in organized garden projects. Geoforum 39(3):12281240.

Purcell, M., and S. K. Tyman. 2014. Cultivating food as a right to the city. Local Environment 20(10):1132-1147.

Ramírez, M. M. 2015. The elusive inclusive: Black food geographies and racialized food spaces. Antipode 47(3):748-769.

Reynolds, K. 2015. Disparity despite diversity: social injustice in New York City's urban agriculture system. Antipode 47(1):240-259.

Reynolds, K., and N. Cohen. 2016. Beyond the kale: urban agriculture and social justice activism in New York City. Athens, GA: University of Georgia Press.

Roman-Alcalá, A. 2015. Broadening the land question in food sovereignty to northern settings: a case study of Occupy the Farm. Globalizations 12(4):545-558.

Rosol, M. 2012. Community volunteering as neoliberal strategy? green space production in Berlin. Antipode 44(1):239-257.

Rudolph, K. R., and S. M. McLachlan. 2013. Seeking Indigenous food sovereignty: origins of and responses to the food crisis in northern Manitoba, Canada. Local Environment 18(9):1079-1098.

Sayer, D. 1989. The Violence of abstraction: the analytic foundations of historical materialism. Oxford: Basil Blackwell.

Sbicca, J. 2012. Growing food justice by planting an anti-oppression foundation: opportunities and obstacles for a budding social movement. Agriculture and Human Values 29(4):455-466.

Sbicca, J. 2016. These bars can't hold us back: Plowing incarcerated geographies with restorative food justice. Antipode 48(5):1359-1379.

Scheromm, P. 2015. Motivations and practices of gardeners in urban collective gardens: the case of Montpellier. Urban Forestry \& Urban Greening 14(3):735-742.

Schmelzkopf, K. 2002. Incommensurability, land use, and the right to space: community gardens in New York City. Urban Geography 23(4):323-343.

Schupp, J., and J. Sharp. 2012. Exploring the social bases of home gardening. Agriculture and Human Values 29(1):93-105.

Smit, J., A. Ratta, and J. Nasr. 1996. Urban agriculture: food, jobs and sustainable cities. New York: United Nations Development Programme.

Smith, C. M., and H. E. Kurtz. 2003. Community gardens and politics of scale in New York City. Geographical Review 93(2):193-212.

Snow, D. A. 2008. Framing processes, ideology, and discursive fields. In The Blackwell companion to social movements, eds. D. A. Snow, S. A. Soule, and H. Kriesi, 380-412. New York: John Wiley \& Sons.

Staeheli, L. A., D. Mitchell, and K. Gibson. 2002. Conflicting rights to the city in New York's community gardens. GeoJournal 58(2/3):197-205.

Tavernise, S. 2011. Vegetable gardens are booming in a fallow economy. The New York Times, 8 Sep. http://www.nytimes.com/2011/09/09/us/09gardening.html. Accessed 30 Jan 2012.

Taylor, J. R., and S. T. Lovell. 2014. Urban home food gardens in the Global North: research traditions and future directions. Agriculture and Human Values 31(2):285-305.

Taylor, J. R. 2015. Urban home gardens in the Global North: a mixed methods study of ethnic and migrant home gardens in Chicago, IL. Renewable Agriculture and Food Systems 30 (1):22-32.

Tornaghi, C. 2014. Critical geography of urban agriculture. Progress in Human Geography 38(4):551-567.

Travaline, K., and C. Hunold. 2010. Urban agriculture and ecological citizenship in Philadelphia. Local Environment 15(6):581-590.

van Veenhuizen, R. 2006. Cities farming for the future: urban agriculture for green and productive cities. Ottawa: IDRC/RUAF.

Viljoen, A. 2005. Continuous productive urban landscapes: designing urban agriculture for sustainable cities. Oxford: Elsevier.

Ville de Montréal. 2012. Etat de l'agriculture urbaine à Montréal. Rapport de consultation publique. Montreal: Office de Consultation Publique de Montréal. http://ocpm.qc.ca/sites/ocpm.qc.ca/files/pdf/P58/rapport_au.pdf. Accessed 10 Mar 2017.

Vitiello, D., and L. Wolf-Powers. 2014. Growing food to grow cities? the potential of agriculture for economic and community development in the urban United States. Community Development Journal 49(4):508-523. 
Waterman, S. D. 1918. History of the Berkeley schools. Berkeley: The Professional Press.

Weber, C. L., and H. S. Matthews. 2008. Food-miles and the relative climate change impacts of food choices in the United States. Environmental Science \& Technology 42(10):3508-3513.

Weissman, E. 2015. Entrepreneurial endeavors: (re)producing neoliberalization through urban agriculture youth programming in Brooklyn, New York. Environmental Education Research 21(3):351-364.

White, M. M. 2011. D-Town Farm: African American resistance to food insecurity and the transformation of Detroit. Environmental Practice 13(4):406-417.

Wittman, H., A. A. Desmarais, and N. Wiebe eds. 2012. Food sovereignty in Canada: creating just and sustainable food systems. Halifax, NS: Fernwood Publishing Co., Ltd.

\section{Author biographies}

Nathan McClintock PhD, is Assistant Professor in the Toulan School of Urban Studies and Planning at Portland State University. He received his $\mathrm{PhD}$ in geography from UC Berkeley and MS in crop science/agroecology from North Carolina State University. His research and teaching focuses on urban agriculture and food systems, urban political ecology, and critical urban theory.

Michael Simpson is a PhD candidate in the Department of Geography at the University of British Columbia. He received his MA in political science from the University of Victoria and MURP from Portland State University. His research focuses on the political ecology of settler colonialism and resource extraction in Canada and the United States. 